\title{
Effect of Gamma-ray on Producing Induced Colour Centres and on Positron Annihilation Lifetime of Bismuth-doped zinc Sodium Borate Glasses
}

\author{
A. H. Ghanem ${ }^{1 *}$ and K.R. Mahmoud ${ }^{2}$ \\ (1) Physics Department, Faculty of Science, Fayoum University, Fayoum, Egypt. \\ (2) Physics Department, Faculty of Science, Kafr Elsheikh University, 33516, El Gaish Street, Kafr El Sheikh, Egypt.
}

\begin{tabular}{|c|c|}
\hline ARTICLE INFO & ABSTRACT \\
\hline Article history: & \multirow{8}{*}{$\begin{array}{l}\text { A melt quenching method have been used for preparing a glass composition of the } \\
\text { form }(70-x) \% \mathrm{~B}_{2} \mathrm{O}_{3}-15 \% \mathrm{ZnO}-15 \% \mathrm{Na}_{2} \mathrm{O}-\mathrm{x} \% \mathrm{Bi}_{2} \mathrm{O}_{3} \text { (where } \mathrm{x}=0,5,10,15,20,25 \text { mol \%). } \\
\text { The prepared glass was studied by FTIR and Positron annihilation lifetime } \\
\text { measurements. FTIR analysis after } 80 \mathrm{kGy} \gamma \text {-irradiation of bismuth-doped glass samples, } \\
\text { show the dependence of the number of structural units } \mathrm{BO}_{3} \text { and } \mathrm{BO}_{4} \text { on the } \gamma \text {-irradiation } \\
\text { dose. FTIR absorption spectra revealed that gamma irradiation produces a degree of a } \\
\text { disorder or defects of the glass network which producing colour centres. The objective } \\
\text { FTIR spectra were used to estimate the } \mathrm{N}_{4} \text { ratio and its dependence on the composition. } \\
\text { Positron annihilation lifetime measurements were carried out for all samples before and } \\
\text { after } 80 \mathrm{kGy} \gamma \text {-irradiation. Irradiated samples show a colour change, which is most likely } \\
\text { due to the formation of colour centres. Such colour changes due to } \gamma \text {-irradiation allow } \\
\text { estimating that the prepared glass samples can be used as a shielding material or as a } \\
\text { radiation indicator sensor. }\end{array}$} \\
\hline Received: $28^{\text {th }}$ Dec. 2020 & \\
\hline Accepted: $1^{\text {st }}$ Apr. 2021 & \\
\hline Keywords: & \\
\hline $\begin{array}{l}\text { Bismuth borate glass, Gamma- } \\
\text { ray irradiation, Infrared } \\
\text { spectroscopy, Positron }\end{array}$ & \\
\hline Annihilation Lifetime & \\
\hline spectroscopy, & \\
\hline Colour centres. & \\
\hline
\end{tabular}

\section{1-INTRODUCTION}

Glasses are important materials used in a radiation shielding. Shielding properties of the glass materials for gamma radiation and neutron sources can be improved by the addition of suitable modifier oxides. These modifiers are heavy metal oxides and have been used as an external agent in the glass compositions such as $\mathrm{Bi}_{2} \mathrm{O}_{3}, \mathrm{PbO}, \mathrm{CuO}$,..etc. [1, 2].

Gamma irradiation may produce a glass defect due to the change in the valence state of lattice and impurity atoms. Thus, glass becomes coloured due to the formation of colour centres [3, 4]. The formation of centres is of many types according to the glass composition [5, 6]. They are associated with optical absorption bands and EPR signals. Several spectroscopic techniques are used to describe the defect centres or colour centres induced by ionizing radiation as optical absorption, infrared and Raman spectroscopy [7] and positron annihilation lifetime spectroscopy $[8,9]$.

Positron annihilation lifetime (PAL) spectroscopy is one of the most remarkable techniques to investigate open volume in amorphous materials [10-12]. The positron annihilation life is measured using a sodium isotope $\left({ }^{22} \mathrm{Na}\right)$ as a positron source to be placed between two identical samples to be measured. Positrons will slow down after implantation into the investigated samples. There are three different pathways to positron annihilation. The first is the direct annihilation process with an electron, the second and third processes are called Positronium (Ps) which occurs after the formation of a positron-bound state with an electron. They depend on the relative spin of the two particles. These are Parapositronium (p-Ps) and Ortho-positronium (o-Ps). Parapositronium (p-Ps) occurs when the two relative spins are anti-parallel, while ortho-positronium (o-Ps) occurs when the two relative spins are parallel. Para-Ps ( $p$-Ps anti-parallel spin) and Ortho-Ps ( $o$-Ps parallel spin) can be found in a vacuum with intrinsic lifetimes 0.125 and $140 \mathrm{~ns}$ respectively [13]. The o-Ps is localized in a freevolume hole or pore. Its lifetimes shorten to 1-10 ns and could be related to the free volume hole size depending on the free volume properties of the prepared sample[14]. Each lifetimes component $\left(\tau_{\mathrm{i}}\right)$ of positron annihilation has a corresponding intensity $\left(\mathrm{I}_{\mathrm{i}}\right)$ related to 
the relative number of annihilations occurring at a particular lifetime. The o-Ps intensity $\left(\mathrm{I}_{\mathrm{o}-\mathrm{Ps}}\right)$ is proportional to the number of free volume holes. Therefore, the Positron annihilation lifetime (PAL) technique gives valuable information on both the average size and the relative number of free volume holes probed by o-Ps.

The main objective of the present work is to study the effect of $80 \mathrm{kGy} \gamma$-irradiation on the formation of defect centres or colour centres. The study includes Fourier transform infrared spectroscopy (FTIR) and Positron annihilation lifetime (PAL) spectroscopy in addition to density, molar volume, $\mathrm{x}$-ray diffraction and energy band gap discussed in previous articles $[15,16]$ needed for this investigation. The investigated glassy system with purity up to $99.5 \%$ has the composition (70x) $\% \mathrm{~B}_{2} \mathrm{O}_{3}-15 \% \mathrm{ZnO}-15 \% \mathrm{Na}_{2} \mathrm{O}-\mathrm{x} \% \mathrm{Bi}_{2} \mathrm{O}_{3}(\mathrm{x}=5,10,15$, $20,25 \mathrm{~mol} \%)$.

\section{2-Experimental Procedures}

Infrared absorption spectra of the prepared glass samples (70-x)\% $\mathrm{B}_{2} \mathrm{O}_{3}-15 \% \mathrm{ZnO}-15 \% \mathrm{Na}_{2} \mathrm{O}-\mathrm{x} \% \mathrm{Bi}_{2} \mathrm{O}_{3}$ (x $=5,10,15,20,25 \mathrm{~mol} \%)^{15,16}$ after $80 \mathrm{kGy} \gamma$-irradiation has been measured at room temperature in the range $400-4000 \mathrm{~cm}^{-1}$. Fourier Transform infrared spectrometer of the type (Thermo Nicolet 200 spectrometer) was used. The prepared glass samples were ground as a fine powder and mixed with potassium bromide $(\mathrm{KBr})$ at a ratio 1: $100 \mathrm{mg}$. The mixtures were subjected to a pressure of $12 \mathrm{ton} / \mathrm{cm}^{2}$ to produce small homogeneous pellets. The infrared absorption measurements are measured immediately after preparing the pellets.

The fast-fast coincidence spectrometer [17] with a resolution of $\sim 350 \mathrm{ps}$ using a ${ }^{60} \mathrm{Co}$ source at room temperature was used for the positron lifetime measurements. About $15 \mu \mathrm{Ci}$ of ${ }^{22} \mathrm{Na}$ activity was deposited and dried on a thin Kapton foil (7.6 $\mu \mathrm{m}$ thick). It is covered with an identical foil and afterward glued with epoxy glue. This assembly was used as the positron source sandwiched between two indistinguishable samples. Each sample was measured at least 2-3 times differed by a total number of elementary annihilation events in the range of 1- 2 million counts. The obtained spectra were analyzed using the L.T. computer program of Kansy [18], with a suitable correction for the positrons annihilated in the Kapton.

Three-lifetime components $\left(\tau_{1}, \tau_{2}\right.$, and $\left.\tau_{3}\right)$ were produced from the analysis of the measured spectra. The first- lifetime component $\tau_{1}$ is due to the Par-Positronium
(p-Ps) atom, which is fixed to the value $0.125 \mathrm{~ns}$. While the intermediate lifetime component $\tau_{2}$ is attributed to the direct annihilation of positrons with an electrons. However, the longest lifetime component $\tau_{3}$ is related to the annihilation of Ortho-Positronium by "pick off" mechanism in the free volume sites present in the amorphous regions [19]. All these components were determined by the fit's variance ranged from 1.005 to 1.18. The determination of the o-Ps lifetime components, $\tau_{3}$, provides valuable information about the mean size of free volume cavities probed by o-Ps. The third-lifetime component of the o-Ps according to the free-volume model [14], is given by the expression [20, 21]:

$\tau_{3}=0.5\left[1-\left(\frac{R}{\delta R+R}\right)+(1 / 2 \pi) \operatorname{Sin}\left(\frac{2 \pi R}{\delta R+R}\right)\right]^{-1}$

Where $\mathrm{R}$ is the free volume radius, $\mathrm{R}_{0}$ is the spherical potential well radius and $\delta R=R_{0}-R=1.656 \AA$ is the fitted empirical electron layer thickness. With this value of $\delta R$, the free volume radius $\mathrm{R}$ was calculated from Eqn.1 and the average size of the free volume holes $V_{f}$ was determined from $V_{f}=(4 / 3) \pi R^{3}$ (in $\AA^{3}$ ). Furthermore, the free volume hole fraction, $F_{v}$, can be found from the empirical equation [22]:

$\mathrm{F}_{\mathrm{v}}=\mathrm{C} \mathrm{V}_{\mathrm{f}} \mathrm{I}_{3}$

where $\mathrm{V}_{\mathrm{f}}$ is in angstrom cube and $C$ is an arbitrarily chosen scaling factor for a spherical cavity.

\section{3-RESULTS AND DISCUSSIONS}

X-ray diffraction patterns of the prepared glass samples listed in table 1 before and after $80 \mathrm{kGy}$ gamma irradiation that studied in the previous articles $[15,16$, 23 ] are shown in fig. 1. The figure exhibits no sharp peaks confirming the non-crystalline nature. Moreover, it reveals that the irradiated samples show a hump which might be due to form small crystallites in the nano range.

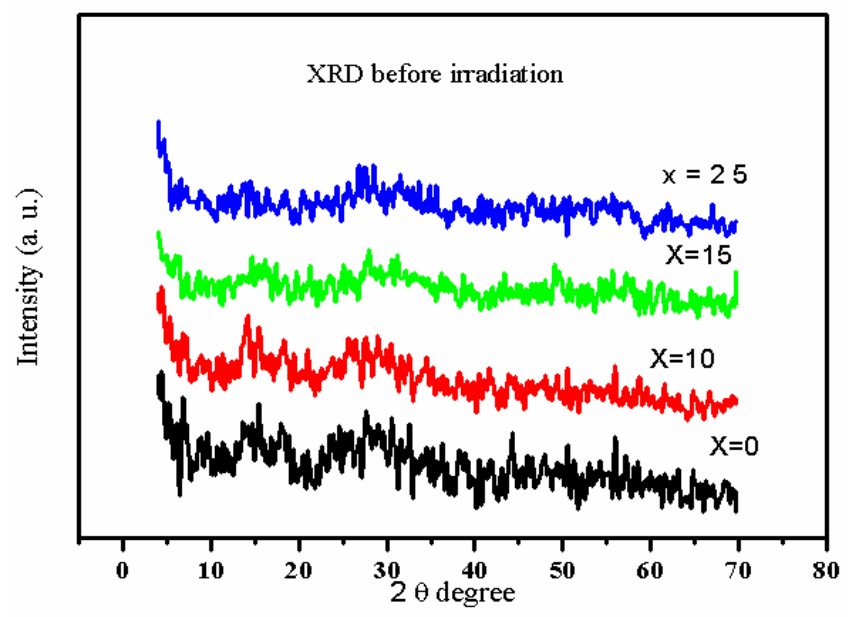

Arab J. Nucl. Sci. Appl., Vol. 54, 3, (2021) 


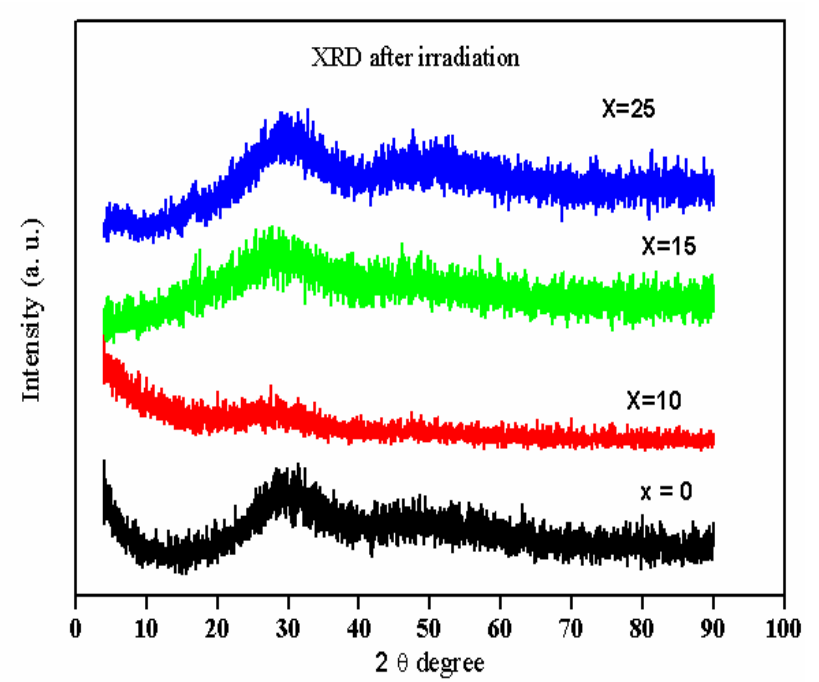

Fig. (1): XRD pattern of the glass samples before and after 80 kGy $\gamma$-irradiation

\section{Table (1): Compositions of glasses (in mol \%)} prepared in the present work.

\begin{tabular}{ccccc}
\hline $\mathbf{X}$ & \multicolumn{5}{c}{ Glass system } \\
\hline 0 & $70 \mathrm{~B}_{2} \mathrm{O}_{3}$ & $0 \mathrm{Bi}_{2} \mathrm{O}_{3}$ & $15 \mathrm{ZnO}$ & $15 \mathrm{Na}_{2} \mathrm{O}$ \\
5 & $65 \mathrm{~B}_{2} \mathrm{O}_{3}$ & $5 \mathrm{Bi}_{2} \mathrm{O}_{3}$ & $15 \mathrm{ZnO}$ & $15 \mathrm{Na}_{2} \mathrm{O}$ \\
10 & $60 \mathrm{~B}_{2} \mathrm{O}_{3}$ & $10 \mathrm{Bi}_{2} \mathrm{O}_{3}$ & $15 \mathrm{ZnO}$ & $15 \mathrm{Na}_{2} \mathrm{O}$ \\
15 & $55 \mathrm{~B}_{2} \mathrm{O}_{3}$ & $15 \mathrm{Bi}_{2} \mathrm{O}_{3}$ & $15 \mathrm{ZnO}$ & $15 \mathrm{Na}_{2} \mathrm{O}$ \\
20 & $50 \mathrm{~B}_{2} \mathrm{O}_{3}$ & $20 \mathrm{Bi}_{2} \mathrm{O}_{3}$ & $15 \mathrm{ZnO}$ & $15 \mathrm{Na}_{2} \mathrm{O}$ \\
25 & $45 \mathrm{~B}_{2} \mathrm{O}_{3}$ & $25 \mathrm{Bi}_{2} \mathrm{O}_{3}$ & $15 \mathrm{ZnO}$ & $15 \mathrm{Na}_{2} \mathrm{O}$ \\
\hline
\end{tabular}

FTIR absorption spectra of the prepared glass samples after $80 \mathrm{kGy} \gamma$-irradiation as well as that before irradiation that was discussed in the previous article [23] are shown in Fig.2.

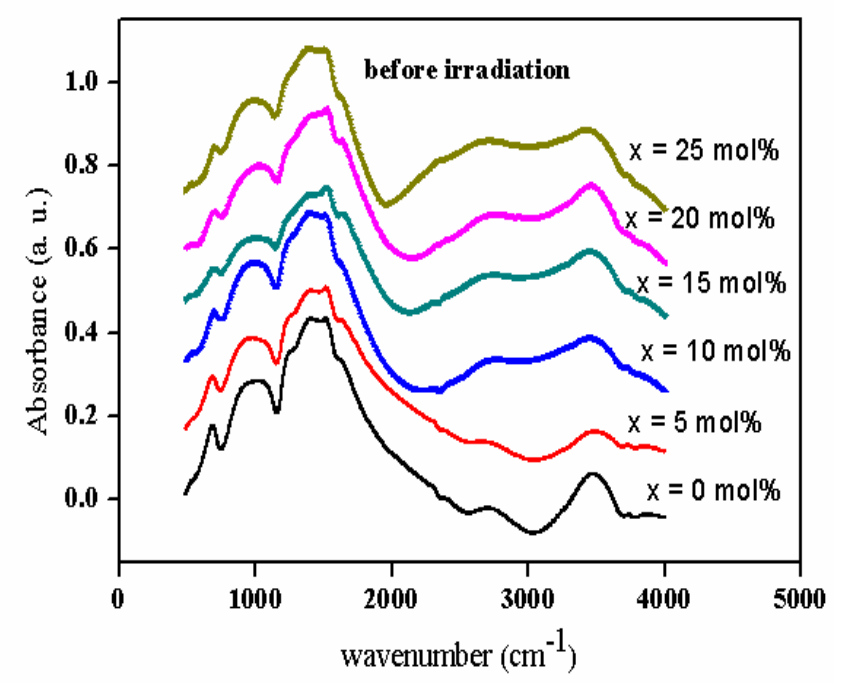

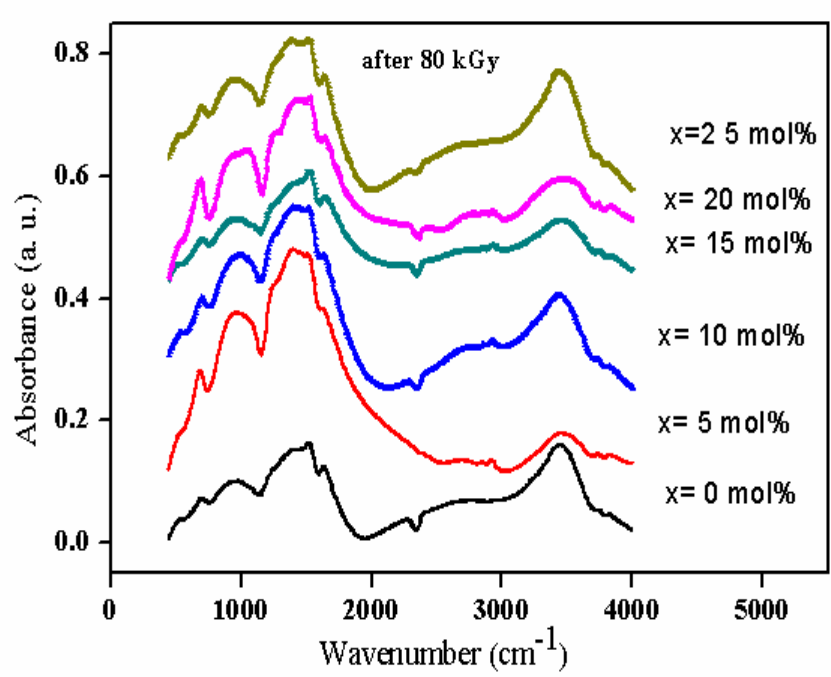

Fig. (2): Infrared spectra of the investigated glass (70-x) $\mathrm{B}_{2} \mathrm{O}_{3}$ $\mathrm{xBi}_{2} \mathrm{O}_{3}-15 \mathrm{ZnO}-15 \mathrm{Na}_{2} \mathrm{O}$ mol\% before and after 80 kGy $\gamma$-irradiation.

The figure reveals that $\gamma$-irradiation does not affect on the band positions. The only observed changes are in the intensity of the bands. FTIR intensity of the bands for each $\mathrm{Bi}_{2} \mathrm{O}_{3}$ concentrations of the glass samples after $80 \mathrm{kGy} \gamma$-irradiation in the region $500-1600 \mathrm{~cm}^{-1}$ are decreased than the corresponding one before irradiation except at $5 \mathrm{~mol} \%$. The decrease in the intensity of these bands with the higher $\mathrm{Bi}_{2} \mathrm{O}_{3}$ concentrations is attributed to the gamma-ray distorted the octahedral $\mathrm{BiO}_{6}$ units into two groups of $\mathrm{BiO}_{3}$ of short and long $\mathrm{Bi}-\mathrm{O}$ bonds and forming $\mathrm{BO}_{3}$ structural units $[24,25]$. This result agrees very well with the increase in the values of $\mathrm{N}_{4}$ ratio after $80 \mathrm{kGy} \gamma$ irradiation than the corresponding one before irradiation when $\mathrm{Bi}_{2} \mathrm{O}_{3}$ concentration changes up to $25 \mathrm{~mol} \%$ as listed in Table 2, where the ratio $\mathrm{N}_{4}$ is defined as the ratio of [concentration $\mathrm{BO}_{4}$ units / concentration of $\left(\mathrm{BO}_{4}\right.$ $+\mathrm{BO}_{3}$ ) units]. The increase in $\mathrm{N}_{4}$ ratio means a decrease in $\mathrm{BO}_{4}$ tetrahedral units which responsible for the increase in the non-bridging oxygen and vacancies. Therefore, $\gamma$-irradiation, due to liberating oxygen bonds, producing a degree of disorder or defect centres of the present glass samples referred to colour centres $[3,5]$. These colour centres are responsible for changing the glass colours from yellow to dark brown [15]. Also, the increase in the intensity after $80 \mathrm{kGy} \gamma$-irradiation than that before irradiation for each $\mathrm{Bi}_{2} \mathrm{O}_{3}$ concentration in the region $2500-3500 \mathrm{~cm}^{-1}$ is due to gamma-ray breaks down more water molecules and liberating oxygen bonds that create stable defects in the prepared glass samples[26]. 
Table (2): $\mathrm{N}_{4}$ ratio before and after $80 \mathrm{kGy} \gamma$-irradiation with $\mathrm{Bi}_{2} \mathrm{O}_{3}$ concentration

\begin{tabular}{ccc}
\hline $\begin{array}{c}\mathrm{Bi}_{2} \mathrm{O}_{4} \text { concentration } \\
\text { mol \% }\end{array}$ & $\begin{array}{c}\mathbf{N}_{4} \text { before 80 kGy } \\
\boldsymbol{\gamma} \text {-irradiation }\end{array}$ & $\begin{array}{c}\mathbf{N}_{4} \text { after 80 kGy } \\
\boldsymbol{\gamma} \text {-irradiation }\end{array}$ \\
\hline 5 & 0.34 & 0.396 \\
10 & 0.296 & 0.541 \\
15 & 0.227 & 0.437 \\
20 & 0.327 & 0.416 \\
25 & 0.262 & 0.291 \\
\hline
\end{tabular}

Extensive investigation of the effect of $80 \mathrm{kGy} \gamma$ irradiation on bismuth-doped $\mathrm{ZnO}-\mathrm{Na}_{2} \mathrm{O}-\mathrm{B}_{2} \mathrm{O}_{3}$ glasses reveals that the intensity of the infrared spectral bands in the region 500-1700 $\mathrm{cm}^{-1}$ changes as the bismuth concentrations change. It increases when bismuth concentration reaches to $5 \mathrm{~mol} \%$, decreases when $\mathrm{Bi}_{2} \mathrm{O}_{3}$ concentration changes from $\mathrm{x}=5$ to $15 \mathrm{~mol} \%$, increases when $\mathrm{Bi}_{2} \mathrm{O}_{3}$ concentration changes from $\mathrm{x}=15$ to $20 \mathrm{~mol} \%$, and finally returns to decrease when $\mathrm{Bi}_{2} \mathrm{O}_{3}$ concentration changes from 20 to $25 \mathrm{~mol} \%$. The interpretation of these spectra can be carried out according to the concept introduced by Tarte and Condrate [27, 28] and applied by Dimitriev et al., Dimitrov et al. and Gattef et al.[29-31]. In such case, the deconvoluted spectra and the assignments of the observed bands after $80 \mathrm{kGy} \gamma$-irradiation for the investigated glass samples are given in fig. 3 and tables 3 .
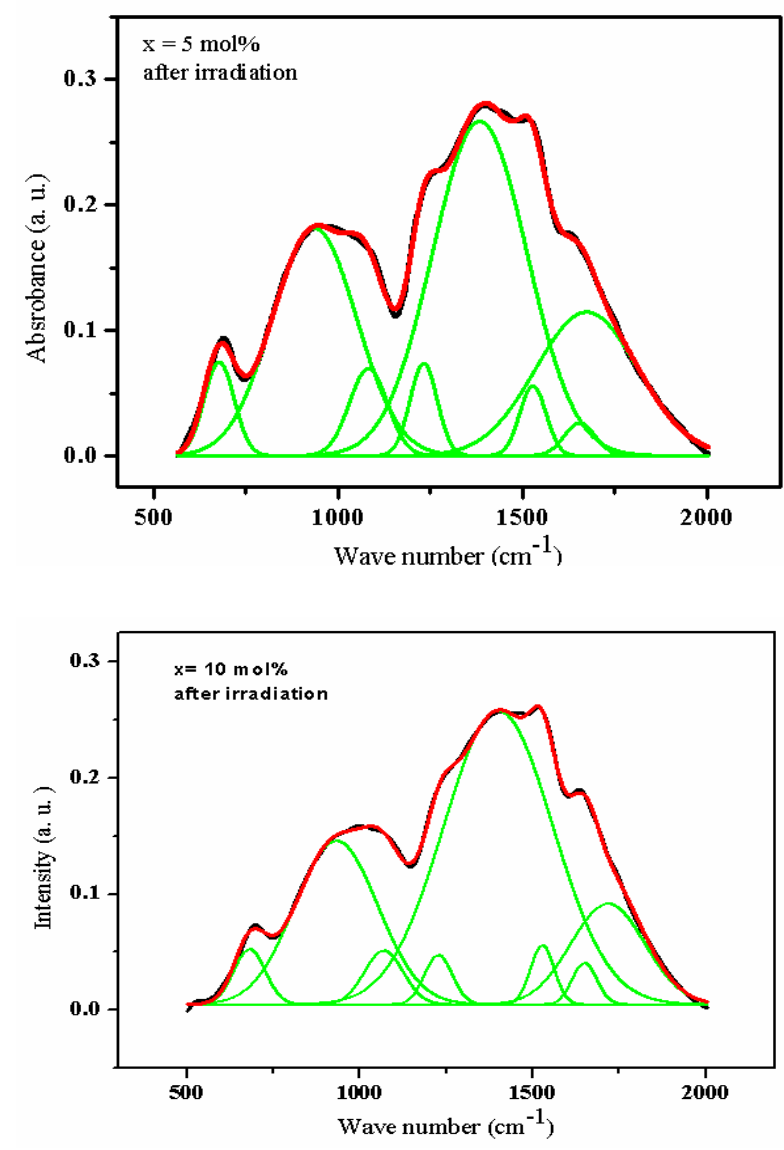
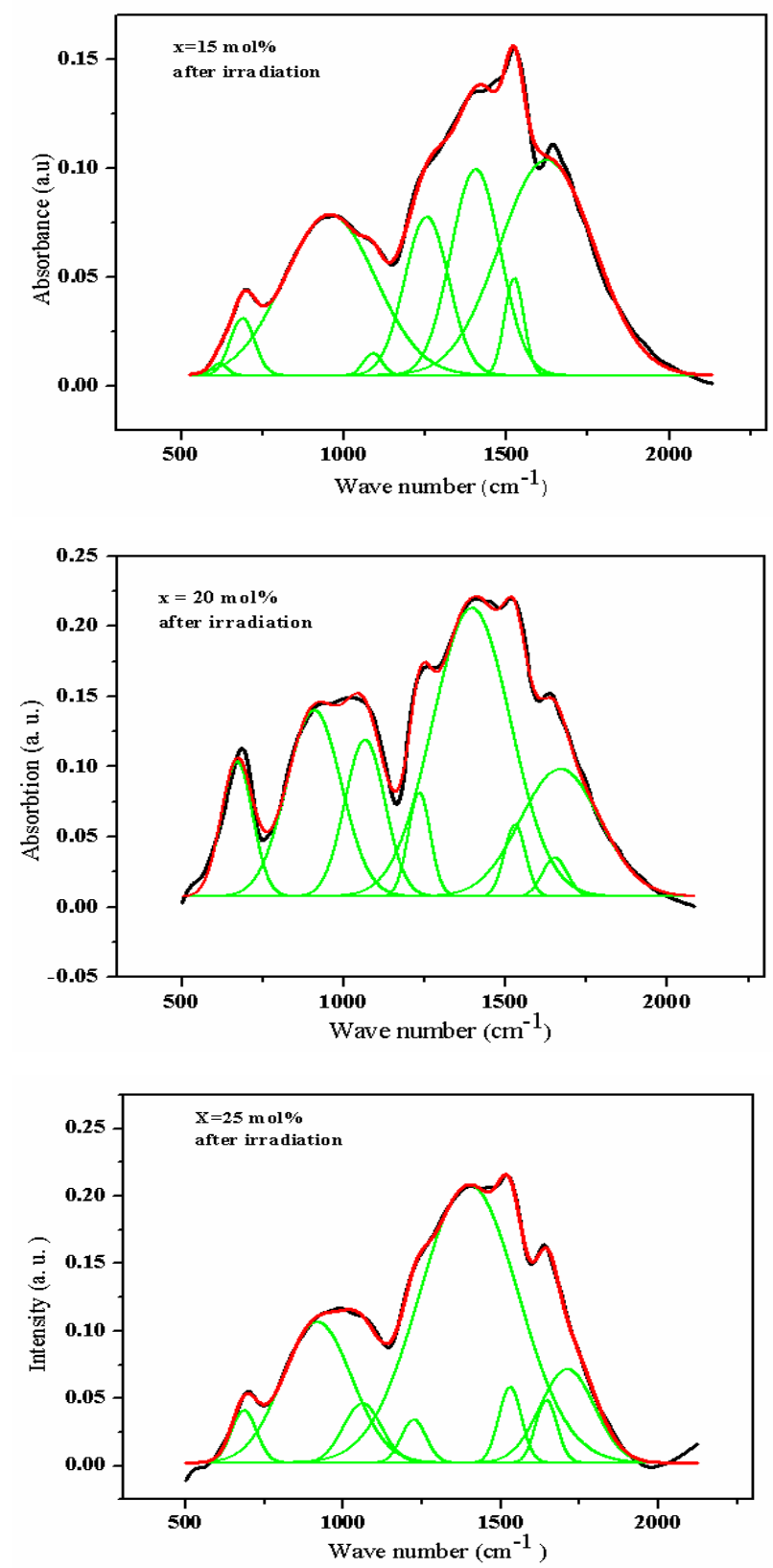

Fig. (3): Deconvolution of the infrared spectrum of the glass (70-x) $\mathrm{B}_{2} \mathrm{O}_{3}-\mathrm{xBi}_{2} \mathrm{O}_{3}-15 \mathrm{ZnO}-15 \quad \mathrm{Na}_{2} \mathrm{O}$ mol\% after 80 kGy $\gamma$-irradiation.

Table (3): Assignments of absorption bands of the infrared spectra of the glass samples $(70-x) \mathrm{B}_{2} \mathrm{O}_{3}-\mathrm{xBi}_{2} \mathrm{O}_{3}-$ $15 \mathrm{ZnO}-15 \mathrm{Na}_{2} \mathrm{O}$ mol \% after $80 \mathrm{kGy}$.

\begin{tabular}{cc}
\hline Wavenumber & IR band assignments $\left(\mathbf{c m}^{-\mathbf{1}}\right)$ \\
\hline $500-600$ & $\mathrm{Bi}-\mathrm{O}-\mathrm{Bi}+\mathrm{Bi}-\mathrm{O}$ in $\mathrm{BiO}_{3}$ group. \\
$600-800$ & $\mathrm{Bi}-\mathrm{O}$ vibration. \\
& $\begin{array}{c}\text { Stretching vibration of } \mathrm{B}-\mathrm{O} \text { bonds of } \\
\mathrm{BO}_{4} \text { units in various structural from tri, } \\
\text { tetra and penta borate groups. } \\
\text { B-O stretching vibrations of trigonal } \\
1300-1700\end{array}$ \\
$\begin{array}{c}\mathrm{BO}_{3} \text { units only. } \\
2000-3500\end{array}$ & Hydrogen bonding of molecular water. \\
\hline
\end{tabular}


The deconvoluted spectra indicate that there is no beak at $830 \mathrm{~cm}^{-1}$, so the vibrations of octahedral $\mathrm{BiO}_{6}$ units will be considered only than trigonal pyramidal $\mathrm{BiO}_{3}$ units ${ }^{(32)}$. The decrease in the FTIR intensity of the bands in the region $800-1200 \mathrm{~cm}^{-1}$ which observed at the peaks $889,1045 \mathrm{~cm}^{-1}$ when $\mathrm{Bi}_{2} \mathrm{O}_{3}$ concentration changes from 5 to $15 \mathrm{~mol} \%$ signify the increase of the local disordering of the structural units due to the conversion of $\mathrm{BO}_{4}$ units into $\mathrm{BO}_{3}$ units and therefore, increasing the non-bridging oxygen and vacancies [33-35]. This is due to $\gamma$-irradiation breaks $\mathrm{Bi}-\mathrm{O}$ bonds of $\mathrm{BiO}_{6}$ and contributes to the $\mathrm{BO}_{4}$ units with $\mathrm{Bi}^{+3}$ ions to form trigonal bipyramidal $\mathrm{BO}_{4} \mathrm{Bi}$ units and producing the nonbridging oxygen $[30,31,36]$. While the increase in the FTIR intensity in the same region with the addition of $\mathrm{Bi}_{2} \mathrm{O}_{3}$ concentration from 15 to $20 \mathrm{~mol} \%$ is due to $\mathrm{Bi}_{2} \mathrm{O}_{3}$ gives its oxygen atom to the boron atom to create a four coordinated state $\left(\mathrm{BO}_{4}\right)$ and bridging oxygen [37]. The conversion to $\mathrm{BO}_{4}$ structural units is consistent with the extensive decreasing in the $\mathrm{N}_{4}$ ratio after $80 \mathrm{kGy} \gamma$ irradiation when $\mathrm{Bi}_{2} \mathrm{O}_{3}$ content increases up to $25 \mathrm{~mol} \%$ as shown in Fig. 4 and listed in Table 2. The decline in $\mathrm{N}_{4}$ ratio indicates the increase in $\mathrm{BO}_{4}$ tetrahedral units at the expense of $\mathrm{BO}_{3}$ trigonal units. This means that the increase in the $\mathrm{Bi}_{2} \mathrm{O}_{3}$ concentration to $25 \mathrm{~mol} \%$ during the exposure of the glass samples to $80 \mathrm{kGy} \gamma$-irradiation producing un-defined structural configuration i.e. a stable defect occurs which referred to a colour centres $[3,5]$. Therefore, the glass with increasing $\mathrm{Bi}_{2} \mathrm{O}_{3}$ content is considered as a good shielding material for radiation[38]. On the other hand, the decrease in the FTIR intensity of the bands in the region $1200-1700 \mathrm{~cm}$ 1 which is observed at the peaks $1227,1383,1513,1630$ cm-1 when $\mathrm{Bi} 2 \mathrm{O} 3$ changes from 5 to 15 mol\% marks the change taking place in the glass structure which results in the transformation of $\mathrm{BO} 3$ structure units to $\mathrm{BO} 4$ units and therefore the non-bridging oxygen, as well as vacancies, decreases $[39,40]$. Moreover, the change in the intensity of the FTIR spectra in the region 600-800 $\mathrm{cm}-1$ which observed at $670 \mathrm{~cm}-1$ are attributed to the combination of the Bi-O vibrational bonds [41, 42] and some superstructure borate units [43]. This is due to the addition of $\mathrm{Bi} 2 \mathrm{O} 3$ responsible for the existence of both $\mathrm{BiO} 3$ and $\mathrm{BiO} 6$ units alone or together $[42,36]$.

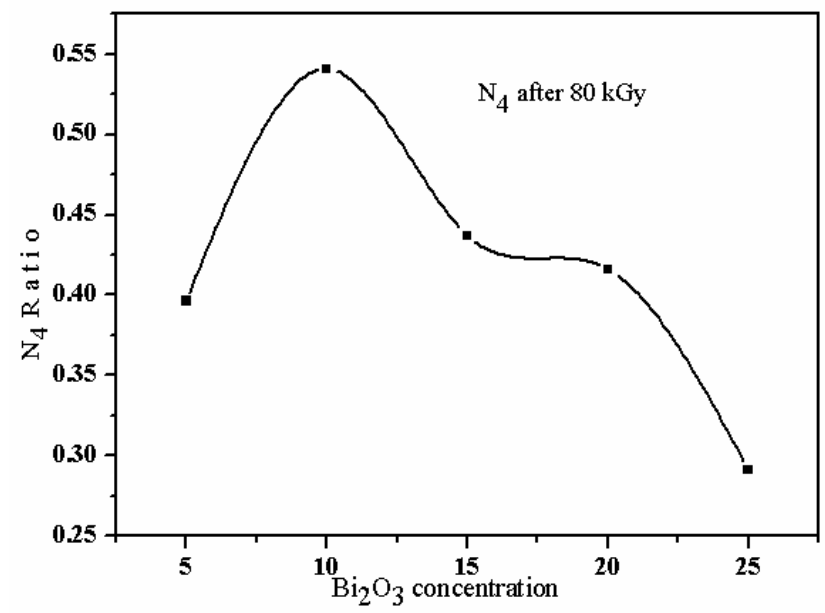

Fig. (4): $\mathrm{N}_{4}$ ratio after $80 \mathrm{kGy} \gamma$-irradiation versus $\mathrm{Bi}_{2} \mathrm{O}_{3}$ concentration.

The above arguments agree very well with the anomalous behaviour of the energy gap and density $\rho$ after $80 \mathrm{kGy} \gamma$-irradiation with the change in $\mathrm{Bi}_{2} \mathrm{O}_{3}$ concentrations [15]. Thus gamma irradiation yields a change in the structural configuration of the characteristic groups in the glass network. Therefore, the obtained FTIR data allows concluding that $\gamma$-irradiation causes cyclic effects i.e. firstly break some chemical bonds of $\mathrm{BO}_{3}$ or $\mathrm{BO}_{4}$ and then reforming other bonds of $\mathrm{BO}_{4}$ or $\mathrm{BO}_{3}$ respectively $[44,45]$. Therefore, gamma irradiation produces a degree of glass network disorder or defects. This results in a change in the optical and physical properties especially to visible colouration which often referred to as colour centres [3,4]. This is confirmed with the change in the colour of the glass samples from yellow to dark brown as gamma irradiation increases from $40 \mathrm{kGy}$ to $80 \mathrm{kGy}$ [15]. Therefore, bismuth borate glass can be used as a shielding material or radiation-sensitive to successive gamma irradiation [3, $38,46,47]$.

Positron annihilation lifetime (PALS) spectra were analyzed before and after $80 \mathrm{kGy} \gamma$-irradiation. The lifetime components $\left(\tau_{1}, \tau_{2}\right.$, and $\left.\tau_{3}\right)$ of positron annihilation have been estimated, along with their intensities $\left(\mathrm{I}_{1}, \mathrm{I}_{2}\right.$ and $\left.\mathrm{I}_{3}\right)$.

Fig. 5 shows the variation dependence of $I_{1}$ on $\mathrm{Bi}_{2} \mathrm{O}_{3}$ concentration before and after 80 kGy $\gamma$-irradiation where its lifetime component is fixed to 125 ps. It reveals that before irradiation $\mathrm{I}_{1}$ intensity decreases from $32 \%$ to $18.7 \%$ when $\mathrm{Bi}_{2} \mathrm{O}_{3}$ concentration changes from $5 \%$ to $10 \mathrm{~mol} \%$. However, when $\mathrm{Bi}_{2} \mathrm{O}_{3}$ content changes from $10 \%$ to $20 \mathrm{~mol} \%, \mathrm{I}_{1}$ is almost constant at about $18.7 \%$ and increases to $28.7 \%$ when $\mathrm{Bi}_{2} \mathrm{O}_{3}$ content 
reaches to $25 \mathrm{~mol} \%$. After $80 \mathrm{kGy} \gamma$-irradiation, $\mathrm{I}_{1}$ increased from $19.7 \%$ to $36 \%$ in the range $(5-20 \mathrm{~mol} \%)$ of $\mathrm{Bi}_{2} \mathrm{O}_{3}$ concentration, then decreased to reach $30.6 \%$ at the $\mathrm{Bi}_{2} \mathrm{O}_{3}$ content of $25 \mathrm{~mol} \%$ for the measured samples. The increase of $\mathrm{I}_{1}$ for the measured samples after $80 \mathrm{kGy}$ $\gamma$-irradiation when $\mathrm{Bi}_{2} \mathrm{O}_{3}$ concentration changes up to 20 mol\% can be attributed to the increase of the free electron concentration which interacts with the positron to form a para-positronium atom. This is may be due to the increase in $\mathrm{Bi}_{2} \mathrm{O}_{3}$ concentration during the exposure of $80 \mathrm{kGy} \gamma$-irradiation decreases the rate of producing the non-bridging oxygen caused by $\gamma$-irradiation. While at higher bismuth concentration of $25 \mathrm{~mol} \%$ there is anomalous behaviour. Although the increase in $\mathrm{Bi}_{2} \mathrm{O}_{3}$ concentration increases $\mathrm{BO}_{4}$ units and bridging oxygen [37] and consequently $I_{1}$ increases, $I_{1}$ decreased. This is confirming that $\gamma$-irradiation produces something change in the glass matrix, i.e. producing the defect centres. This result agrees with the FTIR analysis that gives a conclusion that the higher addition of $\mathrm{Bi}_{2} \mathrm{O}_{3}$ in $\mathrm{ZnO}$ $\mathrm{Na}_{2} \mathrm{O}-\mathrm{B}_{2} \mathrm{O}_{3}$ glasses make them a good shielding material for gamma- radiation.

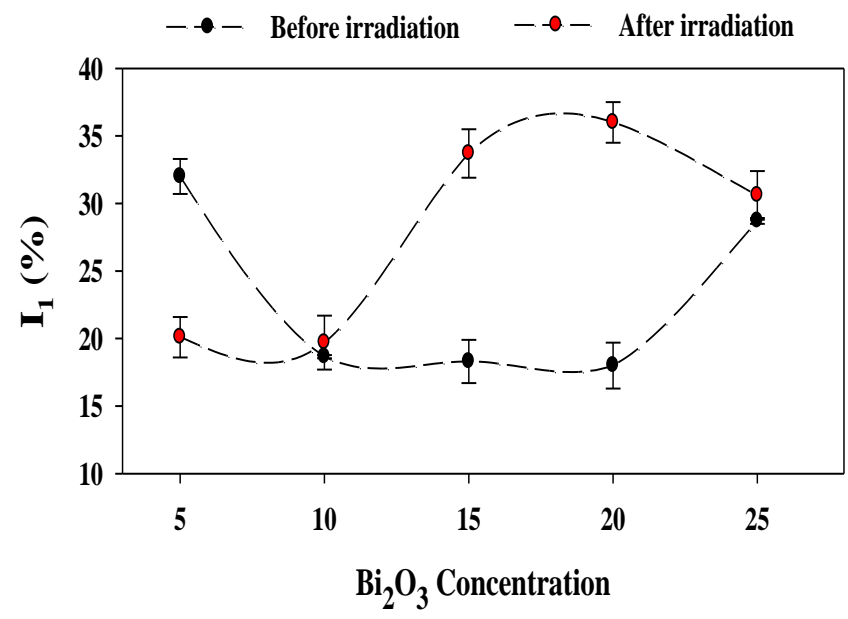

Fig. (5): Variation of $\mathrm{I}_{1}(\%)$ with $\mathrm{Bi}_{2} \mathrm{O}_{3}$ concentration before and after $80 \mathrm{kGy} \gamma$-irradiation.

Fig.6 shows the dependence of intermediate lifetime components $\tau_{2}$ and its intensity $\mathrm{I}_{2}$ on $\mathrm{Bi}_{2} \mathrm{O}_{3}$ concentrations before and after $80 \mathrm{kGy} \gamma$-irradiation. The intermediate lifetime component and its intensity are directly related to the annihilation of trapped positrons with electrons in open volume defects (trapping centres)[48]. The figure shows the lifetime component $\tau_{2}$ before $80 \mathrm{kGy} \gamma$-irradiation is almost the same around $0.35 \mathrm{~ns}$ for all $\mathrm{Bi}_{2} \mathrm{O}_{3}$ contents and its intensity $\mathrm{I}_{2}$ ranged from $67 \%$ to $80.5 \%$. Whereas, after $80 \mathrm{kGy} \gamma$-irradiation $\tau_{2}$ ranged from $0.340 \%$ to 0.445 ns and its intensity $\mathrm{I}_{2}$ ranged from $47.8 \%$ to $79.2 \%$ for all $\mathrm{Bi}_{2} \mathrm{O}_{3}$ contents. On the other hand, the figure shows also that both $\tau_{2}$ and $I_{2}$ before and after $80 \mathrm{kGy} \gamma$-irradiation behaves an opposite trend when $\mathrm{Bi}_{2} \mathrm{O}_{3}$ content changed from 5 to 25 $\mathrm{mol} \%$. The intermediate lifetime $\tau_{2}$ after $80 \mathrm{kGy} \gamma-$ irradiation is gradually increased to a maximum value of 445 ps when $\mathrm{Bi}_{2} \mathrm{O}_{3}$ concentration reaches to $20 \mathrm{~mol} \%$ and then decreased to a minimum value of 342 ps at 25 mol\% $\mathrm{Bi}_{2} \mathrm{O}_{3}$. The increase in $\tau_{2}$ when $\mathrm{Bi}_{2} \mathrm{O}_{3}$ concentration reaches to $20 \mathrm{~mol} \%$, indicates that the effect of $\gamma$-irradiation that enhance the production of the non-bridging oxygen which is associated with the increase of electron density, decreases with the addition of $\mathrm{Bi}_{2} \mathrm{O}_{3}$. This is attributed to the addition of $\mathrm{Bi}_{2} \mathrm{O}_{3}$ increment the bridging oxygen due to it gives more of its oxygen atom to boron atom to form $\mathrm{BO}_{4}$ units [37]. While the decrease in $\tau_{2}$ when $\mathrm{Bi}_{2} \mathrm{O}_{3}$ concentration reaches to the value $25 \mathrm{~mol} \%$, indicates that there is an anomalous behaviour due to $\gamma$-irradiation. This may be attributed to $\gamma$-irradiation makes the rate of increase of $\mathrm{BO}_{3}$ units somewhat greater than the rate of increase $\mathrm{BO}_{4}$ units. This confirming with the decrease in $\mathrm{N}_{4}$ ratio and with the $\gamma$-irradiation producing defect centres. Furthermore, the decrease in the intensity $\mathrm{I}_{2}$ as $\mathrm{Bi}_{2} \mathrm{O}_{3}$ content reaches up to $20 \mathrm{~mol} \%$ reveals that the annihilation process of the present glass occurs mainly either as free annihilation or self-annihilation of $\mathrm{p}$-Ps [49]. The non-linear behaviour of $\tau 2$ and 12 agrees very well with the non-linear behaviour of the density and molar volume discussed before [23].

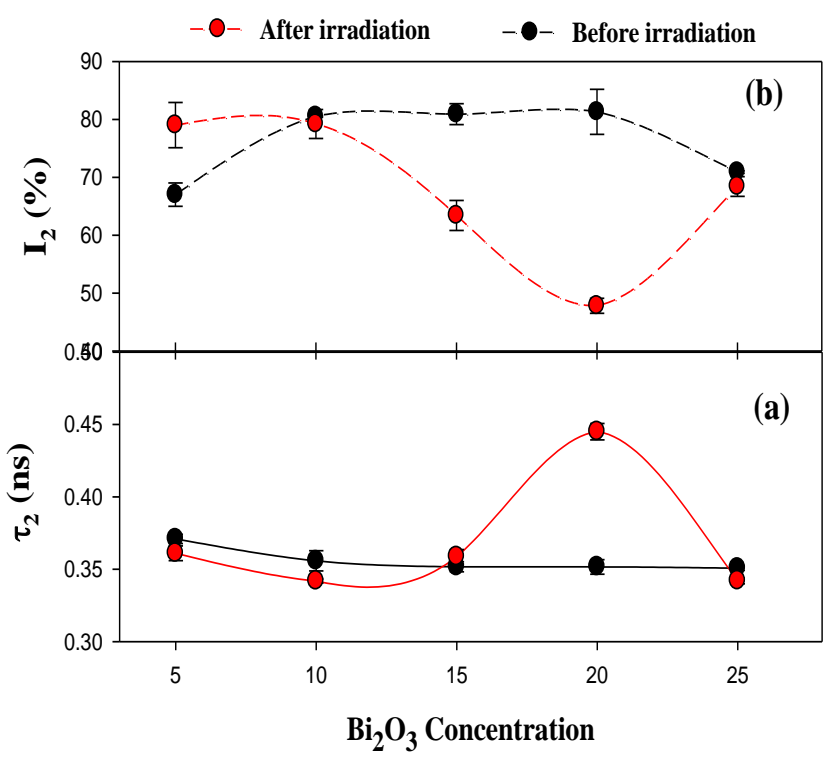

Fig. (6): Variation of (a): $\tau_{2}(\mathrm{~ns})$ and (b): $\mathrm{I}_{2}(\%)$ with $\mathrm{Bi}_{2} \mathrm{O}_{3}$ concentration before and after 80 kGy $\gamma$ irradiation.

The dependence of the lifetime $\tau_{3}$ and its intensity $I_{3}$ (\%), which describe the annihilation parameters of the oPs in amorphous regions, on $\mathrm{Bi}_{2} \mathrm{O}_{3}$ concentration for the measured samples before and after $80 \mathrm{kGy} \gamma$-irradiation Arab J. Nucl. Sci. Appl., Vol. 54, 3, (2021) 
are shown in fig. 7. The figure shows that the behaviour of $\tau_{3}$ with $\mathrm{Bi}_{2} \mathrm{O}_{3}$ concentration before and after $80 \mathrm{kGy} \gamma$ irradiation has the same trend. However, their values after $\gamma$-irradiation are lower than that before $\gamma$-irradiation except at $15 \mathrm{~mol} \% \mathrm{Bi}_{2} \mathrm{O}_{3}$ where $\tau_{3}$ reaches to the higher value 2.015ns. The addition of $\mathrm{Bi}_{2} \mathrm{O}_{3}$ increases the bridging oxygen while $\gamma$-irradiation increases the nonbridging oxygen. Therefore, this agrees with the conclusion that $\gamma$-irradiation producing defect centres in the glass network [3]. On the other hand, fig. 7 shows after $80 \mathrm{kGy} \gamma$-irradiation an opposite trend of $\mathrm{I}_{3}$ and $\tau_{3}$ when $\mathrm{Bi}_{2} \mathrm{O}_{3}$ concentration ranged from 15 to $25 \mathrm{~mol} \%$. The decrement in $\tau_{3}$ and the increment in $\mathrm{I}_{3}$ when $\mathrm{Bi}_{2} \mathrm{O}_{3}$ concentration changes from 15 to $20 \mathrm{~mol} \%$ indicate a decline in the size of free volume holes and consequently the average formation probability for o-Ps increased. This is due to the addition of $\mathrm{Bi}_{2} \mathrm{O}_{3}$ decreases the effect of $\gamma$-irradiation that increment the non-bridging oxygen and vacancies. Therefore, there is a disordered in the glass samples that produce colour centres. While the increase in $\tau_{3}$ and the decrease in $\mathrm{I}_{3}$ when $\mathrm{Bi}_{2} \mathrm{O}_{3}$ concentration changes from 20 to $25 \mathrm{~mol} \%$ indicate an increment in the size of free volume holes. This means that the rate of increment of the non-bridging oxygen is somewhat greater than the increment of bridging oxygen. The same trend in $\tau_{3}$ before and after $\gamma$-irradiation and the difference in their values insure that $\gamma$-irradiation produces stable defects with the increase in $\mathrm{Bi}_{2} \mathrm{O}_{3}$ [3] . This result leads to concluding that $\gamma$-irradiation causes cyclic effects, i.e. first break bonds and reforming other bonds. Thus $\gamma$-irradiation with the addition of $\mathrm{Bi}_{2} \mathrm{O}_{3}$ produces an anomalous behaviour of the glass samples.

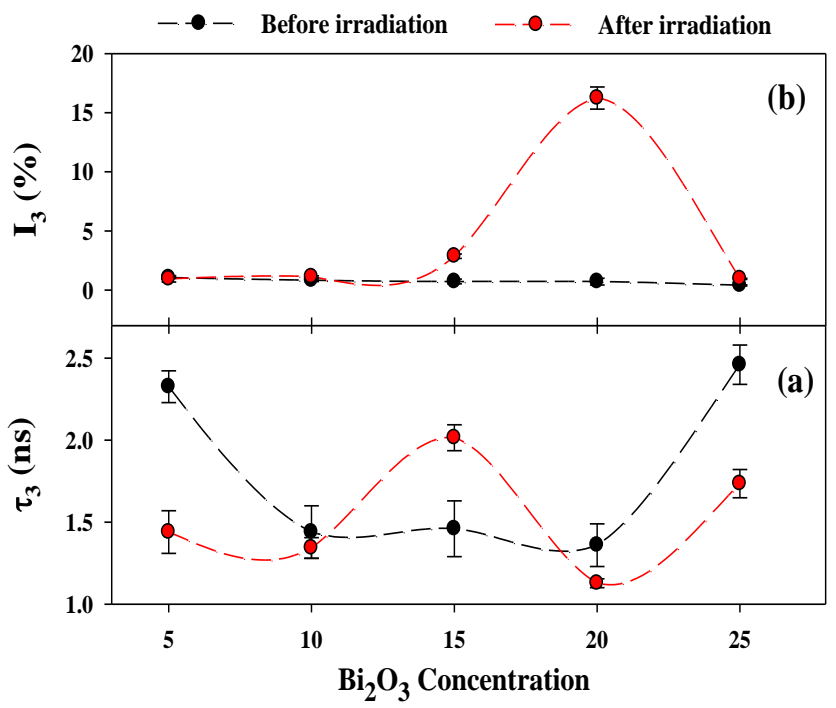

Fig. (7): Variation of (a): $\tau_{3}$ (ns) and (b): $\mathrm{I}_{3}(\%)$ with $\mathrm{Bi}_{2} \mathrm{O}_{3}$ concentration before and after $80 \mathrm{kGy} \gamma$-irradiation.
The variation of free volume hole fraction $\left(\mathrm{F}_{\mathrm{r}} \%\right)$, as calculated using equation (2) of the glass samples before and after $80 \mathrm{kGy} \gamma$-irradiation as a function of $\mathrm{Bi}_{2} \mathrm{O}_{3}$ content is shown in figure 8 . The results showed that before $\gamma$-irradiation $\mathrm{F}_{\mathrm{r}} \%$ decreases from $135 \%$ at $5 \mathrm{~mol} \%$ $\mathrm{Bi}_{2} \mathrm{O}_{3}$ to about $40 \%$ at $10 \mathrm{~mol} \% \mathrm{Bi}_{2} \mathrm{O}_{3}$ and fixed to this value until $25 \mathrm{~mol} \% \mathrm{Bi}_{2} \mathrm{O}_{3}$ concentration. After $80 \mathrm{kGy}$ $\gamma$-irradiation, $\mathrm{F}_{\mathrm{r}} \%$ increases gradually from about 55 at 5 $\mathrm{mol} \%$ of $\mathrm{Bi}_{2} \mathrm{O}_{3}$ concentration to 438 at $20 \mathrm{~mol} \%$ of $\mathrm{Bi}_{2} \mathrm{O}_{3}$ concentration. This may be attributed to the rate of the increment in the percentage of $\mathrm{I}_{3}$ is greater than the rate of decrement in the average size of free volume holes. The result indicates that the increase in $\mathrm{Bi}_{2} \mathrm{O}_{3}$ decline the effect of $\gamma$-irradiation that increases the nonbridging oxygen of the studied glass which associated with defect centres. However, the decrease in $\mathrm{Fr} \%$ value around 65 at $25 \mathrm{~mol} \% \mathrm{Bi}_{2} \mathrm{O}_{3}$ may be attributed to the rate of increment in the average size of free volume holes is less than the rate of decrement in the percentage of $\mathrm{I}_{3}$ or due to the decreasing in $\mathrm{I}_{3} \%$ to small value. This means that $\gamma$-irradiation with the addition of $\mathrm{Bi}_{2} \mathrm{O}_{3}$ produces an anomalous behaviour of the glass samples. The obtained data agree with FTIR analysis and allow to concluding that the addition of a higher quantity of $\mathrm{Bi}_{2} \mathrm{O}_{3}$ to the $\mathrm{ZnO}-\mathrm{Na}_{2} \mathrm{O}-\mathrm{B}_{2} \mathrm{O}_{3}$ glasses improving the shielding properties of the glass.

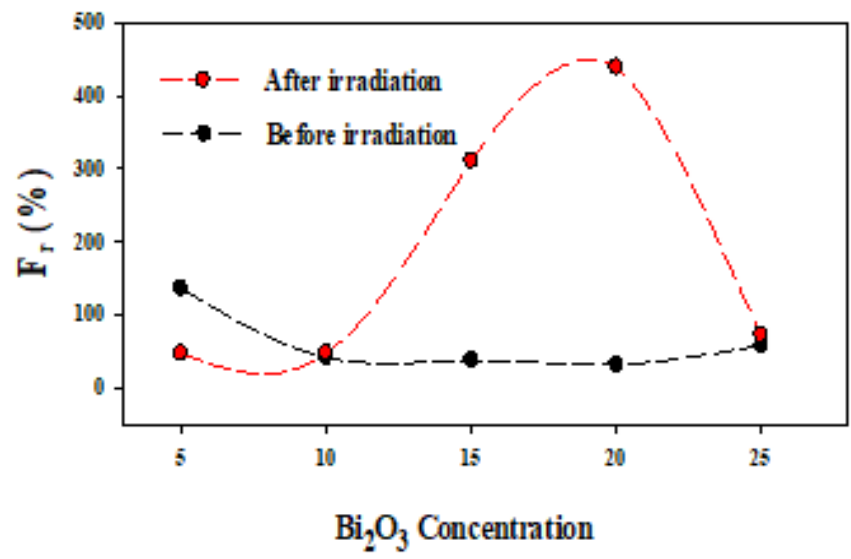

Fig. (8): Variation of $\mathrm{F}_{\mathrm{r}}(\%)$ with $\mathrm{Bi}_{2} \mathrm{O}_{3}$ concentration before and after $80 \mathrm{kGy} \gamma$-irradiation.

\section{CONCLUSION}

The effect of gamma radiation on a bismuth-doped borate glass system of composition $\left(70-\mathrm{x}^{-} \mathrm{B}_{2} \mathrm{O}_{3}-\mathrm{xBi}_{2} \mathrm{O}_{3}-\right.$ $15 \mathrm{ZnO}-15 \mathrm{Na}_{2} \mathrm{O}$ (where $\mathrm{x}=0,5,10,15,20,25$ mol. \%) was studied by using FTIR spectroscopy, and positron annihilation lifetime (PAL) spectroscopy. The obtained results led to the following conclusions:

Gamma radiation was found to have no little effect on the position of the FTIR bands. The only change is in 
these bands' strength. This is attributable to the breakup of $\mathrm{Bi}-\mathrm{O}$ bonds and the formation of $\mathrm{BO}_{3}$ or $\mathrm{BO}_{4}$ units related to the rise or decrease of non-bridging oxygen and vacancies. These can contribute to the development of colour centres and thus the colour of the glass changes from yellow to brown.

The positron annihilation lifetime measurements showed that the intermediate lifetime $\tau_{2}$ of trapped positrons is almost the same for all the measured samples before $\gamma$-irradiation. While for the $80 \mathrm{kGy} \gamma$ irradiated samples, a reduction in $\tau_{2}$ from $445 \mathrm{ps}$ to $342 \mathrm{ps}$ for the sample when $\mathrm{Bi}_{2} \mathrm{O}_{3}$ concentration reaches to 25 mol \%. It can be concluded that $\gamma$-irradiation produces an anomalous behaviour in the structural configuration of the studied glass samples that increasing the rate of increment of $\mathrm{BO}_{3}$ somewhat greater than the rate of increment of $\mathrm{BO}_{4}$ units.

Ortho-positronium trapping in the amorphous region reveals the opposite behaviour of the lifetime $\tau_{3}$ and its intensity $\mathrm{I}_{3}$ when $\mathrm{Bi}_{2} \mathrm{O}_{3}$ content changes from 15 to 25 mol\%. The decreasing of the lifetime $\tau_{3}$ and the increasing of its intensity $\mathrm{I}_{3}$ at lower $\mathrm{Bi}_{2} \mathrm{O}_{3}$ concentration (20 mol\%) indicate that the addition of $\mathrm{Bi}_{2} \mathrm{O}_{3}$ decreases the effect of $\gamma$-irradiation that increment the non-bridging oxygen and vacancies. While the increase in $\tau_{3}$ and the decrease in $\mathrm{I}_{3}$ when $\mathrm{Bi}_{2} \mathrm{O}_{3}$ concentration changes from 20 to $25 \mathrm{~mol} \%$ indicate that $\gamma$-irradiation increases the rate of increment of the non-bridging oxygen is somewhat greater than the increment of bridging oxygen. result lead to concluding that $\gamma$-irradiation causes cyclic effects.

The free volume hole fraction $\left(\mathrm{F}_{\mathrm{r}} \%\right)$ of the glass samples before $\gamma$-irradiation showed a little variation at higher concentration of $\mathrm{Bi}_{2} \mathrm{O}_{3}$. Whereas after $\gamma$ irradiation with $80 \mathrm{kGy}, \mathrm{F}_{\mathrm{r}} \%$ increases to the value of 438 at $20 \mathrm{~mol} \%$ of $\mathrm{Bi}_{2} \mathrm{O}_{3}$ content which may be attributed to the rate of the increment in the percentage of $\mathrm{I}_{3}$ is greater than the rate of decrement in the average size of free volume holes. Whereas, at $25 \mathrm{~mol} \% \mathrm{Bi}_{2} \mathrm{O}_{3}$ content $\mathrm{F}_{\mathrm{r}} \%$ reaches $65 \%$ indicating that $\gamma$-irradiation with the addition of $\mathrm{Bi}_{2} \mathrm{O}_{3}$ produces an anomalous behaviour of the glass samples which produces the defect centres and therefore, the glass becomes coloured.

Finally, it can be concluded that, increasing the content of the bismuth oxide in the borate glass system leads to an enhancement of its characteristics to be used as a gamma radiation detector or as a radiation indicator sensor.

\section{ACKNOWLEDGEMENT}

One of the authors (A. H. Ghanem) would like to thank Prof. M. M. El Okr (Department of physics, Faculty Science, Al Azhar University, Nasr City, Cairo, Egypt) for his support for choosing this compound and for supporting to carry out this work. (Rahemaho Allah).

\section{REFERENCES}

[1] Singh N, Singh K J, Singh K, Singh H, Nucl. Instrum. Methods B225, 305-309 (2004).

[2] El Batal F H, Azooz M A, Ezz El-Din F M, Phys. Chem. Glasses 43, 260-266 (2002).

[3] Lell E, Kreidl N, Hensler J R, Progress in Ceramic Science, 4, P. 1-93 (1966).

[4] Friebele E J, Uhlmann D R, Kreidl N J, American Ceramic Society. Westerville. OH, 205 (1991).

[5] Yokota R, Phys. Rev. 95, 1145-1148 (1954).

[6] Yokota R, Phys. Rev. 101, 522-524 (1956).

[7] Rochada M S F, Pontuschka W M, Blak A R, J. Non-Cryst. Solids 321, 29-36 (2003).

[8] Salama S, Helal A I, Gomaa M A M, Abou-Salem L I, Nafie H, Badawi E A, Tenth Radiation Physics \& Protection Conference, 27-30 November (2010), Nasr City - Cairo, Egypt.

[9] Byrne K S, Pink colouration in natural diamond. PhD Thesis, The school of physics, The University of Western Australia, (2013).

[10] Sreeramalu V, Ravindrachary V, Sreepad H R, Chandrashekara A, Gopal S, Sanjeevaiah H, Viswanathan B, Phys. Status Solidi A117, 53-60 (1990).

[11] Nagel C, Ratzke K, Schmidtke E, Faupel F, Phys. Rev. B 60 (13), 9212- 9215 (1999).

[12] Jean Y C, Mallon P E, Schrader D M, Principles and Application of Positron and Positronium Chemistry (World Scientific, Singapore, 2003).

[13] Mogensen O E, Positron Annihilation in Chemistry (Springer-Verlag, Berlin, 1995). 
[14] Eldrup M, Lightbody D, Sherwood J N, Chem. Phys. 63, 51-58 (1981).

[15] GhanemA H, Atta A, Gaballah N, Arab J. Nucl. Sci. and Applications 50 (4), 134-141(2017).

[16] Ghanem A H, Farag A T M, Abdullah G AlSehemi, Ahmed Al-Ghamdi, Farooq W A, Yakuphanoglu F, Silicon, 10, 1195-1201 (2018). https://doi.org/10.1007/s12633-017-9593-2

[17] Mahmoud K R, Al-Sigeny S, Sharshar T, ElHamshary H, Radiat. Phys. Chem., 75, 590-595 (2006).

[18] Kansy J, Nucl. Instrum. Methods A, 374, 235-244 (1996).

[19] Uchiyama Y, Ito K, Li H L, Ujihara Y, Jean Y C, J. Radioanal Nucl. Chem. 211, 111-117 (1996).

[20] Mc Gonigle E A, Liggat J J, Petherick R A, Jenkins S D, Daly J H, Hayward D, Polymer, 42, 2413 2426 (2001).

[21] Porto A O, Silva G, Magalhães W F, J. Polym. Sci., 37, 219-226 (1999).

[22] Jean Y C, Hong X, Liu J, Huang C M, Cao H, Chung C Y, Dai G H, Cheng K L, Yang H, J. Radioanal Nucl. Chem. 210, 513-518 (1996).

[23] GhanemA H, Gaballah N, IJRDO Journal of Applied Science. 2 (7), 102-120 (20016).

[24] Vegas A, Cano F, Garcia-Blanco S, J. Solid State Chem. 17, 151 (1976).

[25] George H B, Vira C, Stehle C, M.eyer J, Evers S, Hogan O, Feller S, Affatigato M, Phys. Chem. Glasses 40, 326 (1999).

[26] Dunken H, Doremus R H, J. Non-Cryst. Solids 92, 61 (1987).

[27] Tarte P, Physics of Non-Crystalline Solids, Elsevier, Amsterdam, 549(1964).

[28] Condrate R, Introduction to Glass Science, Plenum, New York, 101(1972).
[29] Dimitriev Y, Dimitrov V, Arnandov M, Topalov D, J. Non-Cryst. Solids 57, 147-156 (1983).

[30] Dimitrov V, DimitrievY B \& Montenero A, J. NonCryst. Solids 180, 51-57 (1994).

[31] Gattef E M, Dimitrov V V, Dimitriev Y B, Wright $\mathrm{A} \mathrm{C}$, in Proceeding of the second International Conference on Borates Glasses. Crystals and Melts, Wright A C, Feller S A, Hannon A C, eds., Society of Glass Technology. Sheffield, 112 (1997).

[32] Alharbia T, Hamdy F M Mohamed, Yasser B Saddeek, Ahmed Y El-Haseib, Kh S Shaaban, Radia. Phys. and Chem. 164, 108345 (2019).

[33] Krogh-Moe, J. Phys. Chem. Glasses 6, 46 (1965).

[34] Krogh-Moe, J. Non-Cryst. Solids 1, 269 (1969).

[35] Kamitsos E I, Phys. Chem. Glasses 44, 79 (2003).

[36] Radu A, Baia L, Kiefer W \& Simon S, Vibrational Spectrosc. 39, 127 (2005).

[37] Bishay A \& Maghraby C. Phys. Chem. Glasses 10, 1 (1969).

[38] Singh K, Singh H, Sharma V, Nathuram R, Khama A, Kumar R, Bhatti S S \& Sahta H S, Nucl. Instrum. Meth. Phys. Res. B 194, 1 (2002).

[39] Perince P, Arone A, Marrotta A, Mater. Chem. Glasses 30, 195 (1992).

[40] Perince P, Arone A, Cataura M, Phys. Chem. Glasses 37, 134 (1996).

[41] Zheng H, Xu R\& Mackenzie J, J. Matter. Res. 4, 911 (1989).

[42] Culea E, Pop L, Simon V, Neumann M, \& Bratu L, J. Non-Cryst. Solid 337, 62 (2004).

[43] Meera B N \& Ramakrishra J, J. Non- Cryst. Solid. 159, 1 (1993).

[44] Ehrst D, Vogel W, Nucl. Instum. Methods B 65, 8 (1992).

[45] Sandhu A K, Singh S, Pandey O P, Indian J. Phys., 83 No.7, 985 (2009). 
[46] Bishay A, J. Non-Cryst. Solids 3, 54 (1970).

[47] El Batal F H, Abo Naf S M, Ezz El Din F M, Indian J. Pure Appl. Phys. 34, 579 (2005).

[48] HalynaKlym, Adam Ingram, Oleh Shpotyuk, Laurent Calvez, Elena Petracovschi, Bohdan Kulyk,
Roman Serkiz, Roman Szatanik. Nano-scale Research Letters 10, 49 (2015). DOI 10.1186/s11671-015-0775-9.

[49] Mohsen M, Gomaa E, Al-Kotb M S, Abdel-Baki M, Fathy N, J Non-Cryst. Solids,436, 1-8 (2016). 